\title{
A STUDY OF THE ECONOMIC EFFICIENCY OF TOMATO CROPS FOR THE PRODUCTIVE SEASON 2019 IN NINEVEH GOVERNORATE, ZAMMAR DISTRICT, AS AN EXAMPLE
}

\author{
Ali N. S. Al-Jubouri Nassif J. M.Alihbabi \\ Department of Economics and Agricultural Extension -Agricultural Economics, \\ College of Agriculture, University of Tikrit, Tikrit, Iraq. \\ E-mail: nasaifjasim@tu.edu.iq
}

Reseived: $23 / 7 / 2020, \quad$ Accepted: 12/8 /2020.

\begin{abstract}
The study aimed to measure Economic Efficiency and its components, Technical Efficiency and Allocative Efficiency on the input side, and to impose a change in returns to scale VRS by using the DEA method of data envelope analysis, as well as to review the structure and items of costs for tomato production, and knowing The extent to which economic units achieve a rational use of production resources. the data necessary to study in the field were collected through a questionnaire carried out in a personal interview of (124) farmers of the tomato crop in the open cultivation method in Nineveh Governorate (Zammar district as an application model) for the production season 2019, Included explanatory variables (seeds, fertilizers, pesticides, mechanical work, human work) As for The approved variable is tomato crop production, and the study reached many conclusions, the most important, That three farms $(2.4 \%)$ achieved complete technical, allocation , economic efficiency $(100 \%)$, and the results of showed that the average economic efficiency reached about $(50.8 \%)$, meaning that these farms can achieve the same level Of production in light of reducing production costs by $49.2 \%$, and the study recommended that farmers use resources Economic needs according to the crop's need for these resources and in a way that minimizes costs and maximizes profit, and it is necessary to study the reasons for the success of many farms that have achieved complete Economic Efficiency (100\%), To be references to farms that have not achieved Economic Efficiency Although it in the same circumstances.
\end{abstract}

KeyWords: Economic Efficiency, Technical Efficiency, Allocation Efficiency, Tomato Crop.

\section{INTRODUCTION}

The tomato harvest is one of the crops important for daily use of commodities and services, whether it is sweet, cooked or manufactured for a large percentage of the population, where the consumption of most vegetable crops is concerned to its availability, and it is rich in salts and vitamins necessary for the human physical structure. Iraq is exposed and covered by tunnels and in greenhouses, as it is an

*Part of M.Sc. thesis submitted by the first author. 
important and necessary crop as food and a serious source of income for workers from the social groups contributing to the cultivation of the crop. The tomato is one of the plants of the nightshade family, and it is one of the main vegetable crops in Iraq and the world. It comes at the forefront of summer vegetable crops in terms of daily consumption in various forms. And it lead to an important percentage in the Iraq agricultural economy) Increasing the demand for tomato crops requires providing it in quantities sufficient for the need of local markets, at the very least. Therefore, it is necessary to correct the path of the agricultural process in Iraq from solid agricultural scientific research and the development of short, medium, and longterm plans and good financing to develop the capabilities and skills of farmers in exploiting Land optimization and economic efficiency in agricultural production processes to contribute to improving the income of the farmer and providing the main crops for the country through agricultural growth and self-sufficiency and the progress of the wheel of agricultural development forward, thus achieving food security, maintaining hard currency and supporting the national economy.

The research problem lies in the fact that tomato crop farmers use the elements of production without looking at economic standards in the best role of economic resources, and that reflects the irrational use of available economic resources and thus high production costs,

Research goal measuring Economic Efficiency and its Components, the Technical Efficiency and the Specific Efficiency of the Tomato crop farmers in Nineveh Governorate (Zammar district as an application model) using the DEA data envelope analysis according to the entry guidance model and in light of the change of the VRS size returns, and Estimate the amount of Economic Resources achieved for the Economic Efficiency of the Tomato crop, and estimate the percentage of surplus or deficit in the use of these resources.

The Hypothesis of the Research is that most farmers do not have the ability to choose the optimum combination of production elements because they rely on the inherited skills in crop cultivation away from scientific methods through which the elements of production can be mixed in a way that achieves the optimal combination that minimizes costs, maximizes profit, Consequently, they were not able to make the best use of the resources used, which resulted in a variation in achieving Economic Efficiency and its components in the research sample farms.

\section{MATERIALS AND METHODS}

Economic Efficiency is determined the possibility of obtaining the largest amount of return at the same cost or obtaining the same return at the lowest cost (Debertin, 2012), and Farrell's idea, 1957, explained that the efficiency of a farm consists of two elements. The first is technical competence that represents the farm's ability to obtain the maximum Output from a group of inputs, and the second is the allocative efficiency, which represents the farm's ability to use the inputs at optimal rates (the lowest prices), meaning that there are two ways to calculate the economic efficiency values, which are economic efficiency from the input side (costs) and the economic efficiency is called use or input guidance (Input Orientated Measures), and the economic efficiency of the output (output) and is called the Output 
Orientated Measures. To achieve the objectives of the study, a data envelopment Analysis (DEA) was adopted. This method is defined as a mathematical method that uses linear programming to measure the relative efficiency of a number of administrative units (DMU) Decision Making Units by defining the optimal mixture of an input group and an output group based on her actual performance. (Cooper et al, 2003) The beginning of the data envelope analysis method began in 1957, where Farrell proposed an approach to measure efficiency based on the idea of efficiency curves, and in 1978 Charnes, Cooper and Rhodes first introduced the concept of data envelope analysis Through a prototype focused on trying to estimate possible improvements in inputs (economy in inputs) while achieving the same current level of outputs, assuming what is known in economics as the stability of the return on production (called the Constant Size Economics model) CRS In 1984, (Banke, Charnes, and Cooper) presented another model of data envelope analysis that takes into account the assumption of a change in the return on production (called the Variable Returns of Scale (VRS) model (Al-Rashidi, 2018). The data envelope analysis is one of the frontier analysis methods, it exceeds the methods of measuring efficiency based on cost functions or function production because it estimates efficiency in relation with the best results achieved through the administrative units under analysis and not on the based on average results (Rubenstein, 2005), and therefore data envelope analysis estimates are called Relative Efficiency, and efficiency is derived by a number of institutions that together form the Performance Frontier, which encapsulates all observations, so the institutions (units) that fall on Curve Frontier enjoys the efficiency in the process of distributing its inputs and producing its output while it is considered inefficient for institutions that are not located on the boundary curve, and this method is to evaluate each institution in relation to the best institutions or what is called "Best Performance".(Al-Saqa, 2008). The assumption of CRS stability is proportional only when production is optimal and represents the space and surface of the average cost curve in the long run, but in reality, there are many obstacles that prevent units from achieving these volumes, such as full competition and funding constraints .....etc. As for the assumption of change The VRS yield allows it to measure both technical and customization efficiency, which when estimating it is necessary to have information on input prices (Ali, 2014).

The research was based on a questionnaire that targeted a random sample of (124) farmers of the tomato crop (open cultivation) in the Zammar region for the productive season 2019 , and the sample made up (41\%) of the study population, collected by personal interview and randomly, and included explanatory study variables (seeds) Fertilizers, pesticides, mechanical work and human work) The adopted a variable is the production of tomato crops, and table (1) shows the contribution rate of both fixed and variable costs to the total costs, as it was found that the contribution rate of the variable costs of the tomato crop reached (58.32\%) which is greater From the percentage of the contribution of fixed costs, which amounted to $(41.68 \%)$ of the total costs of the study sample.

Table (1): The percentage of fixed and variable costs Contribution from the total costs of the research sample farms. 
Mesopotamia J. of Agric.

Vo1. (48) No (3) 2020

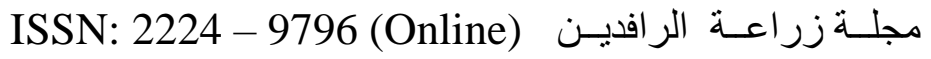

ISSN: 1815 - 316 X (Print) 2020 (48) المجلد (48) العدد (3) اعند (O)

\begin{tabular}{|c|c|c|}
\hline Cost items & The costs/ thousand dinars & contribution percentage\% \\
\hline The Fixed costs & 1403195 & 41.68 \\
\hline The variable costs & 1963163 & 58.32 \\
\hline The Total costs & 3366358 & 100 \\
\hline
\end{tabular}

Source: Prepared by the two researchers using the questionnaire

As for the fixed costs, they were divided into four items: family work, interest on capital, extinction, and land rent. From table (2), it was shown that family work had the largest contribution to fixed costs as it reached $(78.39 \%)$, then interest on capital at a contribution rate $(10.30 \%)$ then the lease of land and extinction $(5.82 \%$, $5.49 \%$ ), respectively, and the interest on capital has been calculated based on the interest rate $(8 \%)$ for short-term loans with the Agricultural Cooperative Bank for the year 2019 .

Table (2): Contribution percentage for fixed cost of the research sample farms.

\begin{tabular}{|c|c|c|}
\hline Fixed costs items & $\begin{array}{c}\text { The costs/ thousand } \\
\text { dinars }\end{array}$ & $\begin{array}{c}\text { contribution } \\
\text { percentage\% }\end{array}$ \\
\hline Familt work & 1099930 & $\% 78.39$ \\
\hline Benefit & 144503 & $\% 10.30$ \\
\hline Extinction & 77071 & $\% 5.49$ \\
\hline The rent & 81691 & $\% 5.82$ \\
\hline The Total Fixed costs & 1403195 & $\% 100$ \\
\hline
\end{tabular}

Source: Prepared by the two researchers using the questionnaire

The variable costs were divided into seven items (seed costs, fertilizer costs, pesticide costs, mechanical work costs (tillage), leased human labor costs, fuel and maintenance costs, transport costs and funds), and the costs of transporting the

Table (3): Contribution percentage for variable cost of the research sample farms.

\begin{tabular}{|c|c|c|}
\hline Variable costs items & $\begin{array}{c}\text { The costs/ thousand } \\
\text { dinars }\end{array}$ & $\begin{array}{c}\text { contribution } \\
\text { percentage\% }\end{array}$ \\
\hline Seeds & 140476 & $\% 7$ \\
\hline Fertilisers & 424081 & $\% 22$ \\
\hline Pesticides & 82267 & $\% 4$ \\
\hline Mechanical work & 63991 & $\% 16$ \\
\hline Leased human work & 315486 & $\% 23$ \\
\hline The fuel and maintenance & 444347 & $\% 25$ \\
\hline Transport and funds & 492515 & $\% 100$ \\
\hline Total & 1963163 & $\%$ \\
\hline
\end{tabular}

Source: Prepared by the two researchers using the questionnaire

product to the markets achieved the highest percentage of the variable costs items (25\%), fuel and maintenance costs came second (23\%), and fertilizer costs came third $(22 \%)$, and the rest of the variable cost items combined (30\%), and table (3) clarifies these details. 
The total area of the study sample farms reached (1121) dunums, and the study sample achieved a productivity rate of (21.12) tons / dunum, where the selling price of the crop fluctuated between (50000 - 600000) dinars per ton, and most of the study sample farms achieved economic profits, while they achieved (22) Loss farm and table (4) shows these details.

Table (4): Average area, production, productivity, cost and revenue rates per ton and dunum per sample of study.

\begin{tabular}{|c|c|}
\hline The details & The value \\
\hline Area / dunum & 1121 \\
\hline Average farm area / dunum & 9.04 \\
\hline Total production / ton & 23677 \\
\hline Average production for farms / ton & 190.94 \\
\hline One dunum productivity: ton/dunum & 21.12 \\
\hline The cost of one dunum / dinar & 3003000 \\
\hline Average sale price: ton/dinar & 244000 \\
\hline Total revenue of one dunum/dinar & 5215000 \\
\hline Net revenue for one dunum/dinar & 2212000 \\
\hline Cost per ton / Dinar & 142000 \\
\hline
\end{tabular}

Source: Prepared by the two researchers using the questionnaire.

\section{RESULTS AND DISCUSSION}

\section{Results of economic efficiency, technical efficiency, and allocation efficiency for the sample:}

Table (5) the results of estimating the economic efficiency, technical efficiency, and allocating efficiency of the total study sample, and the highest value for technical efficiency (TE) was (100\%) and the lowest value was $(39.7 \%)$ with an average of $(73.9 \%)$ and this means that farmers can reduce the quantities used of the elements of production at a rate of $(26.1 \%)$ with the same level of production being achieved, (21) a farm achieved a complete technical efficiency $100 \%$ (16.93\%) of the sample size, and (25) a farm achieved a technical efficiency between $(80 \%)$ and less than ( $100 \%$ (i.e. its percentage) $(20.16 \%)$, (49) achieved a technical efficiency farm between $(60 \%)$ and less than $(80 \%)$ at a rate of $(39.52 \%)$, and (28) achieved a technical efficiency farm between (40\%) and less than (60)\%), I.e. (22.58\%), and one farm achieved technical efficiency less than (40\%) and its percentage $(0.81 \%)$ of the total size of the study sample.

Table (5): Results of estimating economic efficiency, technical efficiency, and locative efficiency for the study sample

\begin{tabular}{|c|c|c|c|c|c|c|c|}
\hline Farm & $\begin{array}{c}\text { Technical } \\
\text { Efficiency } \\
\%\end{array}$ & $\begin{array}{c}\text { Allocative } \\
\text { Efficiency } \%\end{array}$ & $\begin{array}{c}\text { Economic } \\
\text { Efficiency } \\
\%\end{array}$ & Farm & $\begin{array}{c}\text { Technical } \\
\text { Efficiency } \\
\%\end{array}$ & $\begin{array}{c}\text { Allocative } \\
\text { Efficiency } \\
\%\end{array}$ & $\begin{array}{c}\text { Economic } \\
\text { Efficiency } \%\end{array}$ \\
\hline 1 & 0.457 & 0.738 & 0.337 & 64 & 0.519 & 0.899 & 0.466 \\
\hline
\end{tabular}


Mesopotamia J. of Agric.

Vo1. (48) No (3) 2020

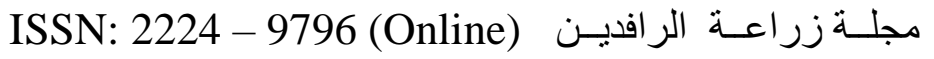

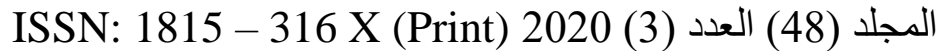

\begin{tabular}{|c|c|c|c|c|c|c|c|}
\hline Farm & $\begin{array}{c}\text { Technical } \\
\text { Efficiency } \\
\%\end{array}$ & $\begin{array}{c}\text { Allocative } \\
\text { Efficiency \% }\end{array}$ & $\begin{array}{c}\text { Economic } \\
\text { Efficiency } \\
\%\end{array}$ & Farm & $\begin{array}{c}\text { Technical } \\
\text { Efficiency } \\
\%\end{array}$ & $\begin{array}{c}\text { Allocative } \\
\text { Efficiency } \\
\%\end{array}$ & $\begin{array}{c}\text { Economic } \\
\text { Efficiency \% }\end{array}$ \\
\hline 2 & 0.530 & 0.786 & 0.416 & 65 & 0.406 & 0.903 & 0.367 \\
\hline 3 & 0.560 & 0.680 & 0.442 & 66 & 0.624 & 0.710 & 0.443 \\
\hline 4 & 0.420 & 0.756 & 0.318 & 67 & 0.594 & 0.607 & 0.361 \\
\hline 5 & 0.748 & 0.629 & 0.470 & 68 & 0.825 & 0.641 & 0.529 \\
\hline 6 & 0.648 & 0.570 & 0.369 & 69 & 0.646 & 0.481 & 0.310 \\
\hline 7 & 0.572 & 0.843 & 0.482 & 70 & 0.658 & 0.539 & 0.355 \\
\hline 8 & 0.550 & 0.652 & 0.359 & 71 & 1.000 & 0.854 & 0.854 \\
\hline 9 & 0.970 & 0.599 & 0.581 & 72 & 0.706 & 0.624 & 0.441 \\
\hline 10 & 1.000 & 0.701 & 0.701 & 73 & 0.894 & 0.444 & 0.397 \\
\hline 11 & 1.000 & 1.000 & 1.000 & 74 & 1.000 & 0.415 & 0.415 \\
\hline 12 & 0.555 & 0.795 & 0.441 & 75 & 1.000 & 0.565 & 0.565 \\
\hline 13 & 0.616 & 0.612 & 0.377 & 76 & 1.000 & 0.562 & 0.562 \\
\hline 14 & 0.646 & 0.630 & 0.407 & 77 & 0.958 & 0.644 & 0.617 \\
\hline 15 & 0.732 & 0.572 & 0.418 & 78 & 0.755 & 0.612 & 0.462 \\
\hline 16 & 0.867 & 0.731 & 0.633 & 79 & 0.659 & 0.609 & 0.401 \\
\hline 17 & 0.826 & 0.629 & 0.520 & 80 & 0.777 & 0.611 & 0.475 \\
\hline 18 & 0.631 & 0.732 & 0.462 & 81 & 0.738 & 0.605 & 0.447 \\
\hline 19 & 0.466 & 0.890 & 0.415 & 82 & 0.751 & 0.616 & 0.463 \\
\hline 20 & 0.526 & 0.756 & 0.397 & 83 & 0.819 & 0.764 & 0.626 \\
\hline 21 & 0.652 & 0.731 & 0.476 & 84 & 0.731 & 0.767 & 0.561 \\
\hline 22 & 0.545 & 0.780 & 0.425 & 85 & 0.938 & 0.439 & 0.411 \\
\hline 23 & 0.545 & 0.775 & 0.422 & 86 & 1.000 & 0.488 & 0.488 \\
\hline 24 & 0.621 & 0.707 & 0.439 & 87 & 0.903 & 0.754 & 0.681 \\
\hline 25 & 1.000 & 0.494 & 0.494 & 88 & 0.752 & 0.521 & 0.392 \\
\hline 26 & 0.562 & 0.677 & 0.380 & 89 & 1.000 & 0.551 & 0.551 \\
\hline 27 & 0.892 & 0.802 & 0.716 & 90 & 1.000 & 0.509 & 0.509 \\
\hline 28 & 0.499 & 0.858 & 0.428 & 91 & 0.939 & 0.442 & 0.415 \\
\hline 29 & 0.637 & 0.733 & 0.467 & 92 & 1.000 & 0.440 & 0.440 \\
\hline 30 & 1.000 & 1.000 & 1.000 & 93 & 0.837 & 0.640 & 0.536 \\
\hline 31 & 1.000 & 0.881 & 0.881 & 94 & 0.987 & 0.747 & 0.738 \\
\hline 32 & 0.897 & 0.760 & 0.682 & 95 & 0.860 & 0.644 & 0.554 \\
\hline 33 & 0.695 & 0.575 & 0.399 & 96 & 0.903 & 0.548 & 0.494 \\
\hline 34 & 0.719 & 0.730 & 0.525 & 97 & 0.763 & 0.940 & 0.717 \\
\hline 35 & 0.732 & 0.722 & 0.528 & 98 & 1.000 & 1.000 & 1.000 \\
\hline 36 & 0.522 & 0.691 & 0.361 & 99 & 1.000 & 0.567 & 0.567 \\
\hline 37 & 0.561 & 0.770 & 0.432 & 100 & 0.709 & 0.571 & 0.405 \\
\hline 38 & 0.452 & 0.807 & 0.365 & 101 & 0.818 & 0.960 & 0.785 \\
\hline 39 & 0.504 & 0.787 & 0.397 & 102 & 0.772 & 0.605 & 0.467 \\
\hline 40 & 0.837 & 0.680 & 0.569 & 103 & 0.619 & 0.699 & 0.432 \\
\hline 41 & 0.837 & 0.679 & 0.568 & 104 & 0.839 & 0.554 & 0.465 \\
\hline 42 & 0.638 & 0.621 & 0.396 & 105 & 1.000 & 0.659 & 0.659 \\
\hline 43 & 0.733 & 0.640 & 0.469 & 106 & 1.000 & 0.765 & 0.765 \\
\hline 44 & 0.446 & 0.778 & 0.347 & 107 & 0.826 & 0.843 & 0.696 \\
\hline 45 & 0.502 & 0.772 & 0.387 & 108 & 0.738 & 0.663 & 0.489 \\
\hline 46 & 0.517 & 0.805 & 0.416 & 109 & 0.738 & 0.654 & 0.483 \\
\hline 47 & 0.613 & 0.754 & 0.462 & 110 & 0.585 & 0.887 & 0.518 \\
\hline 48 & 0.751 & 0.750 & 0.563 & 111 & 0.545 & 0.766 & 0.418 \\
\hline 49 & 1.000 & 0.716 & 0.716 & 112 & 0.545 & 0.775 & 0.423 \\
\hline 50 & 0.625 & 0.796 & 0.497 & 113 & 0.860 & 0.634 & 0.545 \\
\hline 51 & 0.736 & 0.737 & 0.543 & 114 & 1.000 & 0.621 & 0.621 \\
\hline 52 & 0.754 & 0.543 & 0.410 & 115 & 0.604 & 0.556 & 0.336 \\
\hline 53 & 0.608 & 0.704 & 0.428 & 116 & 0.708 & 0.515 & 0.364 \\
\hline 54 & 0.397 & 0.799 & 0.317 & 117 & 1.000 & 0.709 & 0.709 \\
\hline 55 & 0.739 & 0.896 & 0.662 & 118 & 0.479 & 0.724 & 0.347 \\
\hline 56 & 0.637 & 0.649 & 0.413 & 119 & 0.873 & 0.552 & 0.482 \\
\hline 57 & 0.859 & 0.745 & 0.640 & 120 & 0.834 & 0.780 & 0.650 \\
\hline 58 & 0.647 & 0.640 & 0.414 & 121 & 0.694 & 0.739 & 0.513 \\
\hline 59 & 0.662 & 0.649 & 0.430 & 122 & 0.693 & 0.827 & 0.573 \\
\hline
\end{tabular}


Mesopotamia J. of Agric. Vo1. (48) No (3) 2020

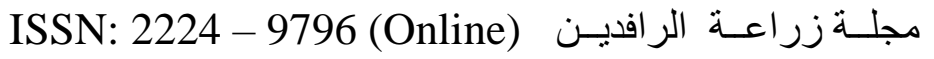
ISSN: 1815 - 316 X (Print) 2020 (48) المجلد (48) العدد (3) اعند (O)

\begin{tabular}{|c|c|c|c|c|c|c|c|}
\hline Farm & $\begin{array}{c}\text { Technical } \\
\text { Efficiency } \\
\%\end{array}$ & $\begin{array}{c}\text { Allocative } \\
\text { Efficiency \% }\end{array}$ & $\begin{array}{c}\text { Economic } \\
\text { Efficiency } \\
\%\end{array}$ & Farm & $\begin{array}{c}\text { Technical } \\
\text { Efficiency } \\
\%\end{array}$ & $\begin{array}{c}\text { Allocative } \\
\text { Efficiency } \\
\%\end{array}$ & $\begin{array}{c}\text { Economic } \\
\text { Efficiency } \%\end{array}$ \\
\hline 60 & 0.560 & 0.693 & 0.388 & 123 & 0.708 & 0.874 & 0.619 \\
\hline 61 & 1.000 & 0.619 & 0.619 & 124 & 0.655 & 0.786 & 0.515 \\
\hline 62 & 0.709 & 0.826 & 0.585 & & & & \\
\hline 63 & 0.651 & 0.855 & 0.557 & Average & 0.739 & 0.696 & 0.508 \\
\hline
\end{tabular}

Source: Prepared by the two researchers based on the data of the questionnaire and the DEAP statistical program

The allocation efficiency is the other, the values of which ranged between the highest value $(100 \%)$ and the lowest value $(41.5 \%)$ and an average of $(69.6 \%)$, where (3) farmers achieved complete allocation efficiency (100\%) at (2.42\%), and achieved (19) A specialty efficiency farm between (80\%) and less than (100\%), i.e. its percentage (15.32\%). Likewise, (76) achieved a specialized efficiency farm between $(60 \%)$ and less than $(80 \%)$, at a rate of $(61.29 \%)$, and achieved (26) A specialized efficiency farm between $(40 \%)$ and less than $(60 \%)$ at $(20.97 \%)$ of the total size of the study sample, as in Table (6).

Table (6): Number and percentage of farms that achieved economic efficiency and components for the total study sample.

\begin{tabular}{|c|c|c|c|c|c|c|}
\hline \multirow{2}{*}{$\begin{array}{c}\text { Efficiency } \\
\text { level }\end{array}$} & \multicolumn{2}{|c|}{ Technical Efficiency } & \multicolumn{2}{c|}{ Allocative Efficiency } & \multicolumn{2}{c|}{ Economic Efficiency } \\
\cline { 2 - 7 } & $\begin{array}{c}\text { Number } \\
\text { of farms }\end{array}$ & Percentage\% & $\begin{array}{c}\text { Number } \\
\text { of farms }\end{array}$ & Percentage\% & $\begin{array}{c}\text { Number } \\
\text { of farms }\end{array}$ & Percentage\% \\
\hline 100 & 21 & 16.93 & 3 & 2.42 & 3 & 2.42 \\
\hline $100<80 \geq$ & 25 & 20.16 & 19 & 15.32 & 2 & 1.61 \\
\hline $80<60 \geq$ & 49 & 39.52 & 76 & 61.29 & 21 & 16.94 \\
\hline $60<40 \geq$ & 28 & 22.58 & 26 & 20.97 & 73 & 58.87 \\
\hline $40<20 \geq$ & 1 & 0.81 & 0 & 0 & 25 & 20.16 \\
\hline Total & 124 & 100 & 124 & 100 & 124 & 100 \\
\hline
\end{tabular}

Source: Prepared by the two researchers, based on Table (5).

As for the economic efficiency, its values ranged between the highest value $(100 \%)$ and the lowest value $(30.10 \%)$ and an average of $(50.80 \%)$, and only three farmers achieved complete economic efficiency (100\%) at a rate of $(2.42 \%)$, which is the same farms that achieved Full technical and allocation efficiency, and (2) a farm achieved economic efficiency between (80\%) and less than (100\%), i.e. its percentage (1.61\%), and (21) a farm achieved economic efficiency between $(60 \%)$ and less than (80\%) by (16.94\%, and (73) farms achieved Economic Efficiency between $(40 \%)$ and less than $(60 \%)$ at a rate of $(58.87 \%)$, and (25) farms achieved Economic Efficiency between (20\%) and less than (40\%) and by (16.16\%) ) Of the total size of the study sample, as shows that in Table (6).

Estimate the size of the economic resources and the amount of surplus and deficit for the total farms of the study sample.

\section{The first resource: The quantity of seeds}

The total amount of seeds used for the total of the study sample was (30812) grams, with an average of (249) grams per farm. From table (7), we notice that the 
Mesopotamia J. of Agric.

Vo1. (48) No (3) 2020
ISSN: 2224 - 9796 (Online) مجــة زراعـة الر افديـن

ISSN: 1815 - 316 X (Print) 2020 (3) الهجلد (48) العدد الرناعن

quantity of seeds achieved for economic efficiency reached an average of (345) grams, meaning that there is a deficit in the amount of seeds used (96) grams (38.6\%). From the results of the analysis, it was found that (3) farms achieved complete economic efficiency with a deficit or a surplus in seed quantity of zero, and (30) farms achieved a surplus, and (91) farms achieved a deficit.

Table (7): The amount of surplus or deficit in the quantity of seeds for the study sample.

\begin{tabular}{|c|c|c|c|c|c|c|c|c|c|}
\hline \multicolumn{5}{|c|}{ Seeds / Gram } & \multicolumn{5}{|c|}{ Seeds / Gram } \\
\hline$\underset{\text { II工 }}{E}$ & E & 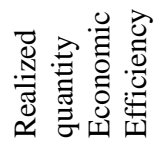 & 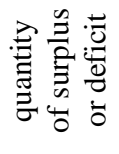 & 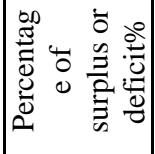 & 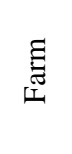 & 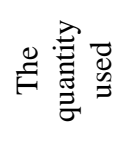 & 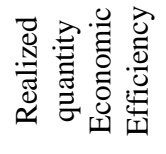 & 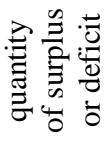 & 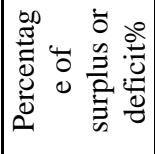 \\
\hline 1 & 500 & 501 & -1 & -0.2 & 64 & 313 & 144 & 169 & 54.0 \\
\hline 2 & 232 & 246 & -14 & -6.0 & 65 & 625 & 297 & 328 & 52.5 \\
\hline 3 & 219 & 341 & -122 & -55.7 & 66 & 288 & 173 & 115 & 39.9 \\
\hline 4 & 375 & 348 & 27 & 7.2 & 67 & 300 & 569 & -269 & -89.7 \\
\hline 5 & 63 & 93 & -30 & -47.6 & 68 & 82 & 161 & -79 & -96.3 \\
\hline 6 & 125 & 182 & -57 & -45.6 & 69 & 188 & 467 & -279 & -148.4 \\
\hline 7 & 313 & 277 & 36 & 11.5 & 70 & 344 & 787 & -443 & -128.8 \\
\hline 8 & 619 & 963 & -344 & -55.6 & 71 & 25 & 50 & -25 & -100.0 \\
\hline 9 & 125 & 246 & -121 & -96.8 & 72 & 169 & 309 & -140 & -82.8 \\
\hline 10 & 94 & 161 & -67 & -71.3 & 73 & 125 & 352 & -227 & -181.6 \\
\hline 11 & 50 & 50 & 0.0 & 0.0 & 74 & 44 & 110 & -66 & -150.0 \\
\hline 12 & 213 & 229 & -16 & -7.5 & 75 & 405 & 908 & -503 & -124.2 \\
\hline 13 & 375 & 807 & -432 & -115.2 & 76 & 405 & 908 & -503 & -124.2 \\
\hline 14 & 250 & 535 & -285 & -114.0 & 77 & 75 & 188 & -113 & -150.7 \\
\hline 15 & 476 & 964 & -488 & -102.5 & 78 & 150 & 343 & -193 & -128.7 \\
\hline 16 & 75 & 86 & -11 & -14.7 & 79 & 282 & 373 & -91 & -32.3 \\
\hline 17 & 188 & 316 & -128 & -68.1 & 80 & 625 & 819 & -194 & -31.0 \\
\hline 18 & 175 & 214 & -39 & -22.3 & 81 & 94 & 214 & -120 & -127.7 \\
\hline 19 & 375 & 82 & 293 & 78.1 & 82 & 188 & 284 & -96 & -51.1 \\
\hline 20 & 188 & 152 & 36 & 19.1 & 83 & 113 & 99 & 14 & 12.4 \\
\hline 21 & 113 & 173 & -60 & -53.1 & 84 & 250 & 150 & 100 & 40.0 \\
\hline 22 & 1094 & 947 & 147 & 13.4 & 85 & 219 & 734 & -515 & -235.2 \\
\hline 23 & 1094 & 947 & 147 & 13.4 & 86 & 94 & 362 & -268 & -285.1 \\
\hline 24 & 250 & 309 & -59 & -23.6 & 87 & 344 & 348 & -4 & -1.2 \\
\hline 25 & 313 & 807 & -494 & -157.8 & 88 & 438 & 979 & -541 & -123.5 \\
\hline 26 & 219 & 407 & -188 & -85.8 & 89 & 157 & 443 & -286 & -182.2 \\
\hline 27 & 63 & 95 & -32 & -50.8 & 90 & 438 & 925 & -487 & -111.2 \\
\hline 28 & 200 & 163 & 37 & 18.5 & 91 & 125 & 411 & -286 & -228.8 \\
\hline 29 & 175 & 288 & -113 & -64.6 & 92 & 100 & 237 & -137 & -137.0 \\
\hline 30 & 1000 & 1000 & 0.0 & 0.0 & 93 & 250 & 420 & -170 & -68.0 \\
\hline 31 & 94 & 144 & -50 & -53.2 & 94 & 94 & 173 & -79 & -84.0 \\
\hline 32 & 282 & 246 & 36 & 12.8 & 95 & 175 & 373 & -198 & -113.1 \\
\hline 33 & 563 & 983 & -420 & -74.6 & 96 & 313 & 896 & -583 & -186.3 \\
\hline 34 & 107 & 105 & 2 & 1.9 & 97 & 500 & 475 & 25 & 5.0 \\
\hline 35 & 144 & 239 & -95 & -66.0 & 98 & 313 & 313 & 0.0 & 0.0 \\
\hline 36 & 300 & 379 & -79 & -26.3 & 99 & 38 & 122 & -84 & -221.1 \\
\hline 37 & 188 & 212 & -24 & -12.8 & 100 & 219 & 543 & -324 & -147.9 \\
\hline 38 & 263 & 161 & 102 & 38.8 & 101 & 750 & 579 & 171 & 22.8 \\
\hline 39 & 338 & 326 & 12 & 3.6 & 102 & 250 & 399 & -149 & -59.6 \\
\hline 40 & 94 & 198 & -104 & -110.6 & 103 & 313 & 450 & -137 & -43.8 \\
\hline 41 & 94 & 198 & -104 & -110.6 & 104 & 94 & 267 & -173 & -184.0 \\
\hline 42 & 132 & 250 & -118 & -89.4 & 105 & 125 & 161 & -36 & -28.8 \\
\hline 43 & 125 & 226 & -101 & -80.8 & 106 & 50 & 52 & -2 & -4.0 \\
\hline 44 & 250 & 124 & 126 & 50.4 & 107 & 313 & 314 & -1 & -0.3 \\
\hline 45 & 332 & 192 & 140 & 42.2 & 108 & 313 & 479 & -166 & -53.0 \\
\hline
\end{tabular}


Mesopotamia J. of Agric.

Vo1. (48) No (3) 2020

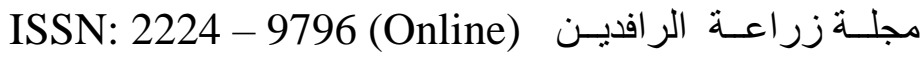
ISSN: 1815 - 316 X (Print) 2020 (48) المجلد (48) العدد (3) اعند (O)

\begin{tabular}{|c|c|c|c|c|c|c|c|c|c|}
\hline \multicolumn{5}{|c|}{ Seeds / Gram } & \multicolumn{5}{|c|}{ Seeds / Gram } \\
\hline 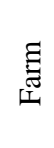 & 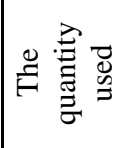 & 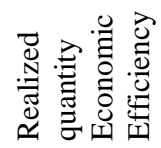 & 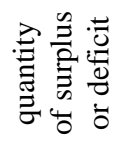 & 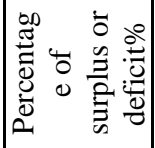 & 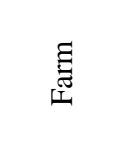 & 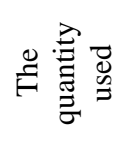 & 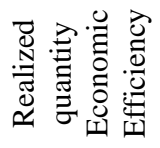 & 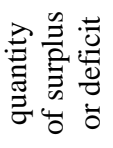 & 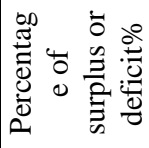 \\
\hline 46 & 157 & 144 & 13 & 8.3 & 109 & 313 & 479 & -166 & -53.0 \\
\hline 47 & 157 & 99 & 58 & 36.9 & 110 & 125 & 86 & 39 & 31.2 \\
\hline 48 & 100 & 148 & -48 & -48.0 & 111 & 469 & 373 & 96 & 20.5 \\
\hline 49 & 57 & 63 & -6 & -10.5 & 112 & 469 & 373 & 96 & 20.5 \\
\hline 50 & 625 & 818 & -193 & -30.9 & 113 & 94 & 139 & -45 & -47.9 \\
\hline 51 & 138 & 260 & -122 & -88.4 & 114 & 64 & 79 & -15 & -23.4 \\
\hline 52 & 88 & 122 & -34 & -38.6 & 115 & 250 & 532 & -282 & -112.8 \\
\hline 53 & 138 & 86 & 52 & 37.7 & 116 & 282 & 628 & -346 & -122.7 \\
\hline 54 & 375 & 280 & 95 & 25.3 & 117 & 38 & 67 & -29 & -76.3 \\
\hline 55 & 94 & 63 & 31 & 33.0 & 118 & 457 & 511 & -54 & -11.8 \\
\hline 56 & 288 & 543 & -255 & -88.5 & 119 & 82 & 101 & -19 & -23.2 \\
\hline 57 & 82 & 156 & -74 & -90.2 & 120 & 82 & 114 & -32 & -39.0 \\
\hline 58 & 350 & 586 & -236 & -67.4 & 121 & 163 & 309 & -146 & -89.6 \\
\hline 59 & 250 & 467 & -217 & -86.8 & 122 & 113 & 118 & -5 & -4.4 \\
\hline 60 & 282 & 297 & -15 & -5.3 & 123 & 157 & 50 & 107 & 68.2 \\
\hline 61 & 63 & 165 & -102 & -161.9 & 124 & 125 & 139 & -14 & -11.2 \\
\hline 62 & 94 & 137 & -43 & -45.7 & & & & & \\
\hline 63 & 219 & 156 & 63 & 28.8 & Average & 249 & 345 & -96 & -38.6 \\
\hline
\end{tabular}

Source: Prepared by the two researchers based on the data of the questionnaire and the DEAP statistical program

\section{The second resource: The amount of fertilizer}

The total amount of fertilizers used at the total of the study sample was $(878,867)$ tons with an average of (7.09) tons for each farm, and from the table (8) we note that the amount of fertilizers achieved for economic efficiency amounted to an average of (4.75) tons, meaning that there is a surplus in the amount of fertilizers used ( 2.34) tons (33\%). From the results of the analysis, it was found that (4) farms achieved complete economic efficiency and the deficit or surplus in the amount of fertilizers was equal to zero, and (72) farms achieved surplus, and (48) farms achieved a deficit.

Table (8): The amount of surplus or deficit in the amount of fertilizers for the study sample.

\begin{tabular}{|c|c|c|c|c|c|c|c|c|c|}
\hline \multicolumn{5}{|c|}{ Fertilizer / Ton } & \multicolumn{5}{|c|}{ Fertilizer / Ton } \\
\hline 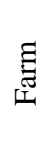 & 导总 & 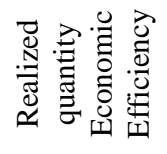 & 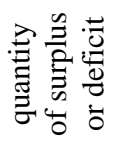 & 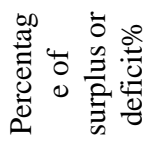 & 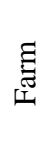 & 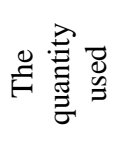 & 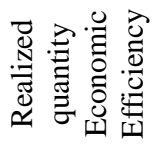 & 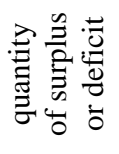 & 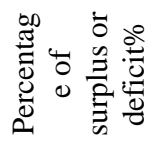 \\
\hline 1 & 12.87 & 6.29 & 6.58 & 51.12 & 64 & 4.50 & 2.48 & 2.02 & 44.91 \\
\hline 2 & 6.43 & 3.57 & 2.86 & 44.51 & 65 & 19.25 & 4.11 & 15.14 & 78.63 \\
\hline 3 & 6.83 & 4.59 & 2.24 & 32.76 & 66 & 2.35 & 2.80 & -0.45 & -18.98 \\
\hline
\end{tabular}


Mesopotamia J. of Agric.

Vo1. (48) No (3) 2020
ISSN: 2224 - 9796 (Online) جلـة زر اعـة الر افديـن

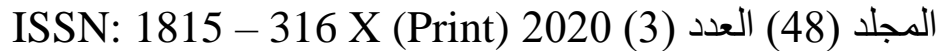

\begin{tabular}{|c|c|c|c|c|c|c|c|c|c|}
\hline \multicolumn{5}{|c|}{ Fertilizer / Ton } & \multicolumn{5}{|c|}{ Fertilizer / Ton } \\
\hline 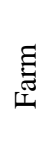 & 导怘 & 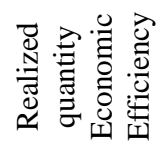 & 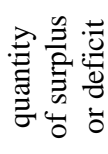 & 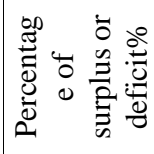 & 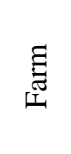 & 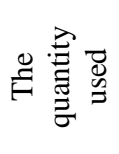 & 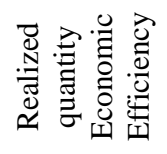 & 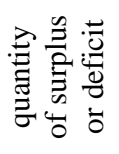 & 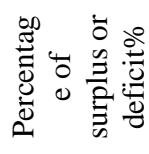 \\
\hline 4 & 10.80 & 4.66 & 6.14 & 56.88 & 67 & 19.25 & 7.02 & 12.23 & 63.54 \\
\hline 5 & 3.08 & 1.93 & 1.14 & 37.11 & 68 & 5.58 & 2.66 & 2.92 & 52.29 \\
\hline 6 & 4.13 & 2.89 & 1.24 & 30.01 & 69 & 7.65 & 5.93 & 1.72 & 22.51 \\
\hline 7 & 7.75 & 3.91 & 3.84 & 49.57 & 70 & 17.60 & 9.36 & 8.25 & 46.85 \\
\hline 8 & 48.93 & 11.47 & 37.46 & 76.56 & 71 & 3.00 & 1.48 & 1.52 & 50.67 \\
\hline 9 & 2.10 & 3.57 & -1.47 & -69.90 & 72 & 2.65 & 4.25 & -1.60 & -60.34 \\
\hline 10 & 1.40 & 2.66 & -1.26 & -90.00 & 73 & 3.00 & 4.70 & -1.70 & -56.77 \\
\hline 11 & 1.48 & 1.48 & 0.00 & 0.00 & 74 & 1.30 & 2.12 & -0.82 & -62.69 \\
\hline 12 & 5.90 & 3.39 & 2.51 & 42.61 & 75 & 4.50 & 11.24 & -6.74 & -149.73 \\
\hline 13 & 7.41 & 9.56 & -2.15 & -29.01 & 76 & 4.50 & 11.24 & -6.74 & -149.73 \\
\hline 14 & 4.94 & 6.66 & -1.72 & -34.72 & 77 & 4.88 & 2.96 & 1.92 & 39.38 \\
\hline 15 & 8.28 & 11.48 & -3.20 & -38.59 & 78 & 3.13 & 4.61 & -1.49 & -47.58 \\
\hline 16 & 1.53 & 1.87 & -0.34 & -21.96 & 79 & 4.50 & 4.93 & -0.43 & -9.56 \\
\hline 17 & 2.08 & 4.32 & -2.24 & -108.05 & 80 & 12.15 & 9.70 & 2.45 & 20.20 \\
\hline 18 & 3.14 & 3.23 & -0.09 & -2.97 & 81 & 3.07 & 3.23 & -0.16 & -5.15 \\
\hline 19 & 13.15 & 2.37 & 10.78 & 81.95 & 82 & 2.10 & 3.98 & -1.88 & -89.38 \\
\hline 20 & 8.70 & 2.57 & 6.13 & 70.47 & 83 & 2.00 & 2.00 & 0.00 & 0.00 \\
\hline 21 & 8.04 & 2.80 & 5.24 & 65.22 & 84 & 12.10 & 2.55 & 9.55 & 78.95 \\
\hline 22 & 26.85 & 11.06 & 15.79 & 58.82 & 85 & 3.13 & 8.79 & -5.66 & -180.77 \\
\hline 23 & 26.85 & 11.06 & 15.79 & 58.82 & 86 & 1.57 & 4.82 & -3.25 & -206.75 \\
\hline 24 & 3.82 & 4.25 & -0.43 & -11.23 & 87 & 17.12 & 4.66 & 12.46 & 72.80 \\
\hline 25 & 4.15 & 9.56 & -5.41 & -130.36 & 88 & 8.20 & 11.40 & -3.20 & -39.00 \\
\hline 26 & 8.40 & 5.29 & 3.11 & 36.99 & 89 & 1.95 & 5.68 & -3.73 & -191.23 \\
\hline 27 & 2.10 & 1.96 & 0.14 & 6.81 & 90 & 10.30 & 11.31 & -1.01 & -9.82 \\
\hline 28 & 13.08 & 2.68 & 10.39 & 79.48 & 91 & 2.70 & 5.34 & -2.64 & -97.70 \\
\hline 29 & 4.15 & 4.02 & 0.13 & 3.08 & 92 & 2.80 & 3.48 & -0.68 & -24.18 \\
\hline 30 & 11.63 & 11.63 & 0.00 & 0.00 & 93 & 4.34 & 5.43 & -1.09 & -25.09 \\
\hline 31 & 2.33 & 2.48 & -0.15 & -6.39 & 94 & 1.86 & 2.80 & -0.94 & -50.32 \\
\hline 32 & 3.87 & 3.57 & 0.30 & 7.80 & 95 & 6.25 & 4.93 & 1.32 & 21.12 \\
\hline 33 & 10.70 & 11.55 & -0.85 & -7.97 & 96 & 7.45 & 10.51 & -3.06 & -41.11 \\
\hline 34 & 1.89 & 2.07 & -0.18 & -9.52 & 97 & 10.05 & 9.43 & 0.62 & 6.21 \\
\hline 35 & 2.95 & 3.50 & -0.55 & -18.64 & 98 & 8.75 & 8.75 & 0.00 & 0.00 \\
\hline 36 & 9.15 & 5.00 & 4.15 & 45.38 & 99 & 3.80 & 2.25 & 1.55 & 40.74 \\
\hline 37 & 4.15 & 3.21 & 0.95 & 22.77 & 100 & 8.10 & 6.75 & 1.36 & 16.73 \\
\hline 38 & 10.25 & 2.66 & 7.59 & 74.05 & 101 & 12.70 & 9.86 & 2.84 & 22.35 \\
\hline 39 & 23.75 & 4.43 & 19.32 & 81.35 & 102 & 7.25 & 5.20 & 2.05 & 28.25 \\
\hline 40 & 2.05 & 3.06 & -1.01 & -49.12 & 103 & 7.30 & 5.75 & 1.55 & 21.27 \\
\hline 41 & 2.05 & 3.06 & -1.01 & -49.12 & 104 & 8.50 & 3.80 & 4.71 & 55.35 \\
\hline 42 & 3.41 & 3.61 & -0.20 & -5.95 & 105 & 1.03 & 2.66 & -1.64 & -159.51 \\
\hline 43 & 3.13 & 3.36 & -0.24 & -7.65 & 106 & 1.46 & 1.50 & -0.04 & -2.80 \\
\hline 44 & 3.35 & 2.27 & 1.08 & 32.12 & 107 & 4.08 & 4.29 & -0.21 & -5.25 \\
\hline 45 & 5.20 & 3.00 & 2.20 & 42.29 & 108 & 5.75 & 6.07 & -0.32 & -5.48 \\
\hline 46 & 4.32 & 2.48 & 1.84 & 42.62 & 109 & 5.75 & 6.07 & -0.32 & -5.48 \\
\hline 47 & 6.00 & 2.00 & 4.00 & 66.63 & 110 & 3.85 & 1.87 & 1.98 & 51.53 \\
\hline 48 & 10.30 & 2.52 & 7.78 & 75.50 & 111 & 12.00 & 4.93 & 7.07 & 58.92 \\
\hline 49 & 4.32 & 1.62 & 2.70 & 62.59 & 112 & 12.00 & 4.93 & 7.07 & 58.92 \\
\hline 50 & 28.58 & 10.86 & 17.72 & 61.99 & 113 & 1.50 & 2.43 & -0.93 & -62.20 \\
\hline 51 & 5.71 & 3.73 & 1.98 & 34.73 & 114 & 1.15 & 1.80 & -0.65 & -56.35 \\
\hline 52 & 6.37 & 2.25 & 4.12 & 64.65 & 115 & 4.75 & 6.63 & -1.88 & -39.62 \\
\hline 53 & 2.25 & 1.87 & 0.38 & 17.07 & 116 & 15.03 & 7.65 & 7.38 & 49.08 \\
\hline 54 & 10.40 & 3.93 & 6.47 & 62.20 & 117 & 2.64 & 1.66 & 0.97 & 36.93 \\
\hline 55 & 2.60 & 1.62 & 0.98 & 37.85 & 118 & 12.15 & 6.41 & 5.75 & 47.28 \\
\hline 56 & 11.43 & 6.75 & 4.69 & 40.99 & 119 & 1.33 & 2.03 & -0.70 & -52.83 \\
\hline 57 & 3.43 & 2.62 & 0.82 & 23.76 & 120 & 5.05 & 2.16 & 2.88 & 57.17 \\
\hline 58 & 11.46 & 7.20 & 4.26 & 37.18 & 121 & 12.55 & 4.25 & 8.30 & 66.14 \\
\hline 59 & 9.17 & 5.93 & 3.24 & 35.35 & 122 & 2.50 & 2.21 & 0.29 & 11.76 \\
\hline
\end{tabular}


Mesopotamia J. of Agric.

Vo1. (48) No (3) 2020

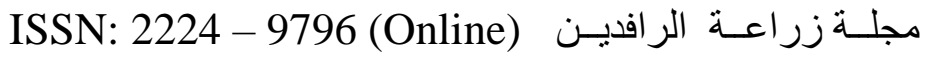
ISSN: 1815 - 316 X (Print) 2020 (48) المجلد (48) العدد (3) اعند (O)

\begin{tabular}{|c|c|c|c|c|c|c|c|c|c|}
\hline \multicolumn{5}{|c|}{ Fertilizer / Ton } & \multicolumn{5}{|c|}{ Fertilizer / Ton } \\
\hline 吾 & 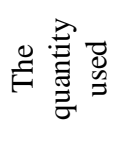 & 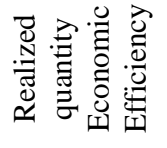 & 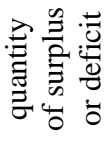 & 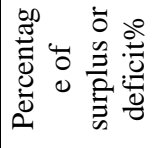 & 売 & 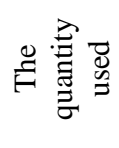 & 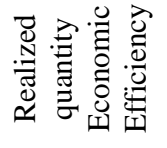 & 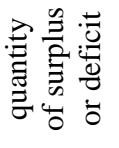 & 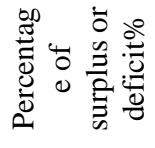 \\
\hline 60 & 4.00 & 4.11 & -0.11 & -2.83 & 123 & 2.25 & 1.48 & 0.77 & 34.22 \\
\hline 61 & 3.40 & 3.02 & 0.38 & 11.09 & 124 & 10.03 & 2.43 & 7.59 & 75.73 \\
\hline 62 & 3.00 & 2.41 & 0.59 & 19.63 & & & & & \\
\hline 63 & 3.95 & 2.62 & 1.34 & 33.80 & Average & 7.09 & 4.75 & 2.34 & 33 \\
\hline
\end{tabular}

Source: Prepared by the two researchers based on the data of the questionnaire and the DEAP statistical program

\section{The third resource: The quantity of pesticides}

The total amount of pesticides used in the total of the study sample was (2997) liters with an average of (24.2) liters per farm, and from Table (9) we note that the amount of pesticides achieved for economic efficiency reached on average (19.6) liters, meaning that there is a surplus in the amount of pesticides used ( 4.6) liters (19\%). From the results of the analysis, it was found that (7) farms achieved complete economic efficiency and the deficit or surplus in the amount of pesticides was equal to zero, and (83) farms achieved a surplus, while (34) farms achieved a deficit.

Table (9): The amount of surplus or deficit in the amount of pesticides for the study sample.

\begin{tabular}{|c|c|c|c|c|c|c|c|c|c|}
\hline \multicolumn{5}{|c|}{ Pesticides / Liter } & \multicolumn{5}{|c|}{ Pesticides / Liter } \\
\hline 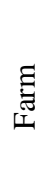 & 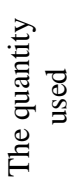 & 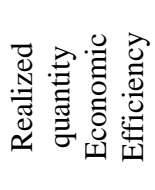 & 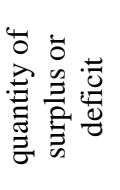 & 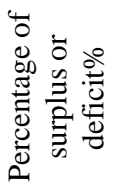 & 志 & 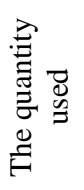 & 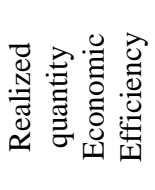 & 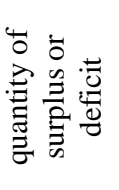 & 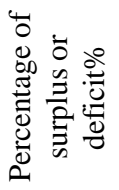 \\
\hline 1 & 41.0 & 26.8 & 14.2 & 34.6 & 64 & 20.0 & 8.7 & 11.3 & 56.5 \\
\hline 2 & 21.0 & 13.9 & 7.1 & 33.8 & 65 & 50.0 & 16.5 & 33.5 & 67.0 \\
\hline 3 & 26.0 & 18.7 & 7.3 & 28.1 & 66 & 25.0 & 10.2 & 14.8 & 59.2 \\
\hline 4 & 26.0 & 19.0 & 7 & 26.9 & 67 & 35.0 & 30.2 & 4.8 & 13.7 \\
\hline 5 & 6.0 & 6.2 & -0.2 & -3.3 & 68 & 14.0 & 9.6 & 4.4 & 31.4 \\
\hline 6 & 9.0 & 10.7 & -1.7 & -18.9 & 69 & 26.0 & 25.1 & 0.9 & 3.5 \\
\hline 7 & 20.0 & 15.5 & 4.5 & 22.5 & 70 & 51.0 & 41.3 & 9.7 & 19.0 \\
\hline 8 & 45.0 & 51.6 & -6.6 & -14.7 & 71 & 10.0 & 4.0 & 6 & 60.0 \\
\hline 9 & 10.0 & 13.9 & -3.9 & -39.0 & 72 & 14.0 & 17.1 & -3.1 & -22.1 \\
\hline 10 & 7.0 & 9.6 & -2.6 & -37.1 & 73 & 20.0 & 19.3 & 0.7 & 3.5 \\
\hline 11 & 4.0 & 4.0 & 0.0 & 0.0 & 74 & 16.0 & 7.0 & 9 & 56.3 \\
\hline 12 & 13.0 & 13.0 & 0.0 & 0.0 & 75 & 30.0 & 50.9 & -20.9 & -69.7 \\
\hline 13 & 52.0 & 42.2 & 9.8 & 18.8 & 76 & 30.0 & 50.9 & -20.9 & -69.7 \\
\hline 14 & 35.0 & 28.5 & 6.5 & 18.6 & 77 & 13.0 & 11.0 & 2 & 15.4 \\
\hline 15 & 30.0 & 51.6 & -21.6 & -72.0 & 78 & 22.0 & 18.8 & 3.2 & 14.5 \\
\hline 16 & 15.0 & 5.8 & 9.2 & 61.3 & 79 & 14.0 & 20.3 & -6.3 & -45.0 \\
\hline 17 & 21.0 & 17.4 & 3.6 & 17.1 & 80 & 40.0 & 42.9 & -2.9 & -7.3 \\
\hline 18 & 23.0 & 12.3 & 10.7 & 46.5 & 81 & 18.0 & 12.3 & 5.7 & 31.7 \\
\hline 19 & 37.0 & 8.9 & 28.1 & 75.9 & 82 & 23.0 & 15.8 & 7.2 & 31.3 \\
\hline 20 & 14.0 & 9.2 & 4.8 & 34.3 & 83 & 6.0 & 6.5 & -0.5 & -8.3 \\
\hline 21 & 17.0 & 10.2 & 6.8 & 40.0 & 84 & 7.0 & 9.1 & -2.1 & -30.0 \\
\hline 22 & 97.0 & 49.3 & 47.7 & 49.2 & 85 & 25.0 & 38.6 & -13.6 & -54.4 \\
\hline 23 & 96.0 & 49.3 & 46.7 & 48.6 & 86 & 13.0 & 19.8 & -6.8 & -52.3 \\
\hline 24 & 30.0 & 17.1 & 12.9 & 43.0 & 87 & 12.0 & 19.0 & -7 & -58.3 \\
\hline 25 & 29.0 & 42.2 & -13.2 & -45.5 & 88 & 43.0 & 50.9 & -7.9 & -18.4 \\
\hline
\end{tabular}


Mesopotamia J. of Agric.

Vo1. (48) No (3) 2020

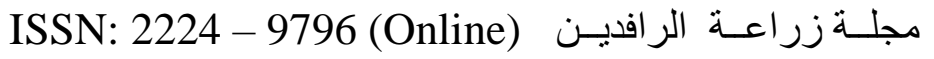

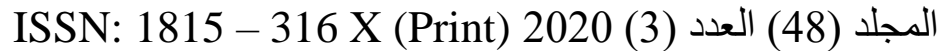

\begin{tabular}{|c|c|c|c|c|c|c|c|c|c|}
\hline \multicolumn{5}{|c|}{ Pesticides / Liter } & \multicolumn{5}{|c|}{ Pesticides / Liter } \\
\hline$\underset{\text { I }}{E}$ & 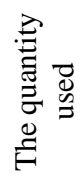 & 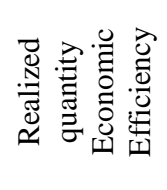 & 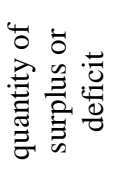 & 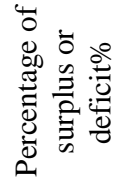 & 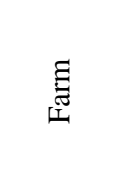 & 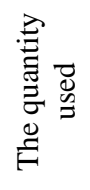 & 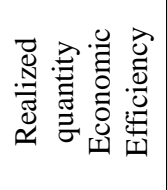 & 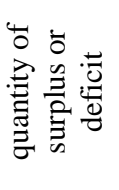 & 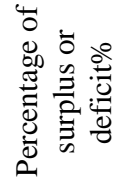 \\
\hline 26 & 32.0 & 22.0 & 10 & 31.3 & 89 & 21.0 & 23.9 & -2.9 & -13.8 \\
\hline 27 & 8.0 & 6.3 & 1.7 & 21.3 & 90 & 27.0 & 51.1 & -24.1 & -89.3 \\
\hline 28 & 15.0 & 9.7 & 5.3 & 35.3 & 91 & 17.0 & 22.3 & -5.3 & -31.2 \\
\hline 29 & 35.0 & 16.0 & 19 & 54.3 & 92 & 12.0 & 13.5 & -1.5 & -12.5 \\
\hline 30 & 52.0 & 52.0 & 0.0 & 0.0 & 93 & 24.0 & 22.7 & 1.3 & 5.4 \\
\hline 31 & 5.0 & 8.7 & -3.7 & -74.0 & 94 & 11.0 & 10.2 & 0.8 & 7.3 \\
\hline 32 & 9.0 & 13.9 & -4.9 & -54.4 & 95 & 21.0 & 20.3 & 0.7 & 3.3 \\
\hline 33 & 40.0 & 51.8 & -11.8 & -29.5 & 96 & 22.0 & 46.7 & -24.7 & -112.3 \\
\hline 34 & 10.0 & 6.8 & 3.2 & 32.0 & 97 & 51.0 & 45.9 & 5.1 & 10.0 \\
\hline 35 & 21.0 & 13.6 & 7.4 & 35.2 & 98 & 44.0 & 44.0 & 0.0 & 0.0 \\
\hline 36 & 35.0 & 20.6 & 14.4 & 41.1 & 99 & 6.0 & 7.7 & -1.7 & -28.3 \\
\hline 37 & 36.0 & 12.2 & 23.8 & 66.1 & 100 & 29.0 & 29.0 & 0.0 & 0.0 \\
\hline 38 & 23.0 & 9.6 & 13.4 & 58.3 & 101 & 52.0 & 47.1 & 4.9 & 9.4 \\
\hline 39 & 35.0 & 18.0 & 17 & 48.6 & 102 & 22.0 & 22.0 & 0.0 & 0.0 \\
\hline 40 & 12.5 & 11.5 & 1 & 8.0 & 103 & 19.0 & 24.2 & -5.2 & -27.4 \\
\hline 41 & 12.5 & 11.5 & 1 & 8.0 & 104 & 12.0 & 15.0 & -3 & -25.0 \\
\hline 42 & 18.0 & 14.1 & 3.9 & 21.7 & 105 & 11.0 & 9.6 & 1.4 & 12.7 \\
\hline 43 & 16.0 & 12.9 & 3.1 & 19.4 & 106 & 6.0 & 4.1 & 1.9 & 31.7 \\
\hline 44 & 18.0 & 7.8 & 10.2 & 56.7 & 107 & 19.0 & 17.3 & 1.7 & 8.9 \\
\hline 45 & 20.0 & 11.2 & 8.8 & 44.0 & 108 & 40.0 & 25.7 & 14.3 & 35.8 \\
\hline 46 & 27.0 & 8.7 & 18.3 & 67.8 & 109 & 40.0 & 25.7 & 14.3 & 35.8 \\
\hline 47 & 12.0 & 6.5 & 5.5 & 45.8 & 110 & 9.0 & 5.8 & 3.2 & 35.6 \\
\hline 48 & 18.0 & 8.9 & 9.1 & 50.6 & 111 & 34.0 & 20.3 & 13.7 & 40.3 \\
\hline 49 & 4.0 & 4.6 & -0.6 & -15.0 & 112 & 34.0 & 20.3 & 13.7 & 40.3 \\
\hline 50 & 79.0 & 49.9 & 29.1 & 36.8 & 113 & 10.0 & 8.5 & 1.5 & 15.0 \\
\hline 51 & 16.0 & 14.6 & 1.4 & 8.8 & 114 & 4.0 & 5.5 & -1.5 & -37.5 \\
\hline 52 & 11.0 & 7.7 & 3.3 & 30.0 & 115 & 23.0 & 28.4 & -5.4 & -23.5 \\
\hline 53 & 7.0 & 5.8 & 1.2 & 17.1 & 116 & 20.0 & 33.2 & -13.2 & -66.0 \\
\hline 54 & 30.0 & 15.6 & 14.4 & 48.0 & 117 & 4.0 & 4.9 & -0.9 & -22.5 \\
\hline 55 & 8.0 & 4.6 & 3.4 & 42.5 & 118 & 33.0 & 27.3 & 5.7 & 17.3 \\
\hline 56 & 57.0 & 28.9 & 28.1 & 49.3 & 119 & 12.0 & 6.6 & 5.4 & 45.0 \\
\hline 57 & 17.0 & 9.4 & 7.6 & 44.7 & 120 & 19.0 & 7.2 & 11.8 & 62.1 \\
\hline 58 & 49.0 & 31.1 & 17.9 & 36.5 & 121 & 20.0 & 17.1 & 2.9 & 14.5 \\
\hline 59 & 39.0 & 25.1 & 13.9 & 35.6 & 122 & 17.0 & 7.4 & 9.6 & 56.5 \\
\hline 60 & 20.0 & 16.5 & 3.5 & 17.5 & 123 & 37.0 & 4.0 & 33 & 89.2 \\
\hline 61 & 11.0 & 11.0 & 0.0 & 0.0 & 124 & 29.0 & 8.5 & 20.5 & 70.7 \\
\hline 62 & 10.0 & 8.4 & 1.6 & 16.0 & & & & & \\
\hline 63 & 17.0 & 9.4 & 7.6 & 44.7 & Average & 24.2 & 19.6 & 4.6 & 19 \\
\hline
\end{tabular}

Source: Prepared by the two researchers based on the data of the questionnaire and the DEAP statistical program

\section{Fourth supplier: The amount of mechanical work}

The total amount of mechanical work used for the total of the study sample was (3263) hours with an average of (26.3) hours for each farm, and the table (10) we note that the amount of mechanical work achieved for economic efficiency amounted to an average (27.4) hours that is, there is a deficit in the amount of work the mechanic used is (1.1-) hour, at a rate of (4.18\%). From the results of the analysis it was found that (4) farms achieved complete economic efficiency and the 
Mesopotamia J. of Agric.

Vo1. (48) No (3) 2020
ISSN: 2224 - 9796 (Online) مجــة زراعـة الر افديـن

ISSN: 1815 - 316 X (Print) 2020 (3) الهجلد (48) العدد الرناعن

deficit or surplus in the amount of mechanical work was equal to zero, and (39) farms achieved surplus, and (81) farms achieved a deficit.

Table (10): amount of surplus or deficit in the amount of mechanical work for the sample of the study.

\begin{tabular}{|c|c|c|c|c|c|c|c|c|c|}
\hline \multicolumn{5}{|c|}{ Mechanical Work / Hour } & \multicolumn{5}{|c|}{ Mechanical Work / Hour } \\
\hline 喆 & 氖鸹导 & 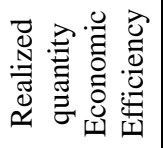 & 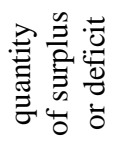 & 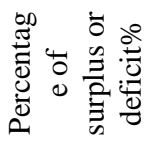 & 馬 & 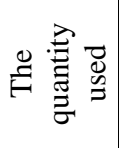 & 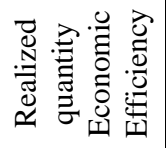 & 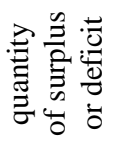 & 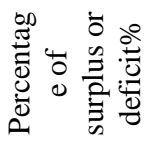 \\
\hline 1 & 90 & 34.4 & 55.6 & 61.8 & 64 & 20 & 14.3 & 5.7 & 28.5 \\
\hline 2 & 45 & 20 & 25 & 55.6 & 65 & 40 & 22.9 & 17.1 & 42.8 \\
\hline 3 & 20 & 25.4 & -5.4 & -27.0 & 66 & 25 & 15.9 & 9.1 & 36.4 \\
\hline 4 & 56 & 25.8 & 30.2 & 53.9 & 67 & 35 & 38.2 & -3.2 & -9.1 \\
\hline 5 & 10.5 & 11.4 & -0.9 & -8.6 & 68 & 7.5 & 15.2 & -7.7 & -102.7 \\
\hline 6 & 17.5 & 16.4 & 1.1 & 6.3 & 69 & 24.5 & 32.5 & -8 & -32.7 \\
\hline 7 & 25 & 21.8 & 3.2 & 12.8 & 70 & 37.5 & 50.5 & -13 & -34.7 \\
\hline 8 & 166.5 & 64 & 102.5 & 61.6 & 71 & 6 & 9 & -3 & -50.0 \\
\hline 9 & 6 & 20 & -14 & -233.3 & 72 & 17.5 & 23.6 & -6.1 & -34.9 \\
\hline 10 & 4 & 15.2 & -11.2 & -280.0 & 73 & 12.5 & 26 & -13.5 & -108.0 \\
\hline 11 & 9 & 9 & 0.0 & 0.0 & 74 & 5 & 12.4 & -7.4 & -148.0 \\
\hline 12 & 36 & 19.1 & 16.9 & 46.9 & 75 & 37.5 & 66.2 & -28.7 & -76.5 \\
\hline 13 & 52.5 & 51.6 & 0.9 & 1.7 & 76 & 37.5 & 66.2 & -28.7 & -76.5 \\
\hline 14 & 35 & 36.3 & -1.3 & -3.7 & 77 & 7.5 & 16.8 & -9.3 & -124.0 \\
\hline 15 & 77 & 63.9 & 13.1 & 17.0 & 78 & 15 & 25.5 & -10.5 & -70.0 \\
\hline 16 & 7.5 & 11 & -3.5 & -46.7 & 79 & 30 & 27.2 & 2.8 & 9.3 \\
\hline 17 & 21 & 24 & -3 & -14.3 & 80 & 37.5 & 52.3 & -14.8 & -39.5 \\
\hline 18 & 15 & 18.2 & -3.2 & -21.3 & 81 & 12.5 & 18.2 & -5.7 & -45.6 \\
\hline 19 & 30 & 19 & 11 & 36.7 & 82 & 14 & 22.2 & -8.2 & -58.6 \\
\hline 20 & 10 & 14.8 & -4.8 & -48.0 & 83 & 7.5 & 11.8 & -4.3 & -57.3 \\
\hline 21 & 14 & 15.9 & -1.9 & -13.6 & 84 & 17.5 & 14.6 & 2.9 & 16.6 \\
\hline 22 & 87.5 & 59.5 & 28 & 32.0 & 85 & 30 & 47.5 & -17.5 & -58.3 \\
\hline 23 & 87.5 & 59.5 & 28 & 32.0 & 86 & 15 & 26.6 & -11.6 & -77.3 \\
\hline 24 & 28 & 23.6 & 4.4 & 15.7 & 87 & 20 & 25.8 & -5.8 & -29.0 \\
\hline 25 & 18 & 51.6 & -33.6 & -186.7 & 88 & 37.5 & 61.3 & -23.8 & -63.5 \\
\hline 26 & 36 & 29.1 & 6.9 & 19.2 & 89 & 15 & 31.1 & -16.1 & -107.3 \\
\hline 27 & 9 & 11.5 & -2.5 & -27.8 & 90 & 22.5 & 65.5 & -43 & -191.1 \\
\hline 28 & 17.5 & 15.3 & 2.2 & 12.6 & 91 & 15 & 29.4 & -14.4 & -96.0 \\
\hline 29 & 24.5 & 22.4 & 2.1 & 8.6 & 92 & 6 & 19.5 & -13.5 & -225.0 \\
\hline 30 & 62.5 & 62.5 & 0.0 & 0.0 & 93 & 17.5 & 29.8 & -12.3 & -70.3 \\
\hline 31 & 7.5 & 14.3 & -6.8 & -90.7 & 94 & 7.5 & 15.9 & -8.4 & -112.0 \\
\hline 32 & 12.5 & 20 & -7.5 & -60.0 & 95 & 15 & 27.2 & -12.2 & -81.3 \\
\hline 33 & 50 & 63.2 & -13.2 & -26.4 & 96 & 35 & 56.6 & -21.6 & -61.7 \\
\hline 34 & 7.5 & 12.1 & -4.6 & -61.3 & 97 & 103.5 & 83.5 & 20 & 19.3 \\
\hline 35 & 15 & 19.7 & -4.7 & -31.3 & 98 & 90 & 90 & 0.0 & 0.0 \\
\hline 36 & 30 & 27.6 & 2.4 & 8.0 & 99 & 9 & 13.1 & -4.1 & -45.6 \\
\hline 37 & 18 & 18 & 0.0 & 0.0 & 100 & 25 & 36.8 & -11.8 & -47.2 \\
\hline 38 & 15 & 15.2 & -0.2 & -1.3 & 101 & 105 & 79.4 & 25.6 & 24.4 \\
\hline 39 & 45 & 24.6 & 20.4 & 45.3 & 102 & 15 & 28.6 & -13.6 & -90.7 \\
\hline 40 & 12.5 & 17.3 & -4.8 & -38.4 & 103 & 54 & 31.5 & 22.5 & $\begin{array}{l}41.7 \\
\end{array}$ \\
\hline 41 & 12.5 & 17.3 & -4.8 & -38.4 & 104 & 12.5 & 21.2 & -8.7 & -69.6 \\
\hline 42 & 15 & 20.3 & -5.3 & -35.3 & 105 & 7.5 & 15.2 & -7.7 & -102.7 \\
\hline 43 & 10 & 18.9 & -8.9 & -89.0 & 106 & 4 & 9.1 & -5.1 & -127.5 \\
\hline 44 & 17.5 & 13.2 & 4.3 & 24.6 & 107 & 20 & 23.8 & -3.8 & -19.0 \\
\hline 45 & 15 & 17 & -2 & -13.3 & 108 & 25 & 33.2 & -8.2 & -32.8 \\
\hline 46 & 15 & 14.3 & 0.7 & 4.7 & 109 & 25 & 33.2 & -8.2 & -32.8 \\
\hline 47 & 7.5 & 11.8 & -4.3 & -57.3 & 110 & 12.5 & 11 & 1.5 & 12.0 \\
\hline 48 & 10 & 14.5 & -4.5 & -45.0 & 111 & 30 & 27.2 & 2.8 & 9.3 \\
\hline 49 & 4.5 & 9.7 & -5.2 & -115.6 & 112 & 30 & 27.2 & 2.8 & 9.3 \\
\hline
\end{tabular}


Mesopotamia J. of Agric.

Vo1. (48) No (3) 2020

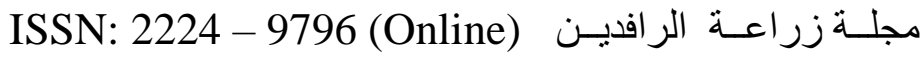
ISSN: 1815 - 316 X (Print) 2020 (48) المجلد (48) العدد (3) اعند (O)

\begin{tabular}{|c|c|c|c|c|c|c|c|c|c|}
\hline \multicolumn{5}{|c|}{ Mechanical Work / Hour } & \multicolumn{5}{|c|}{ Mechanical Work / Hour } \\
\hline 嫣 & 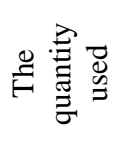 & 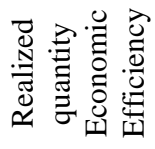 & 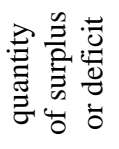 & 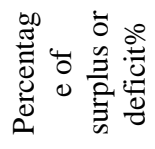 & 志 & 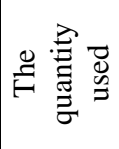 & 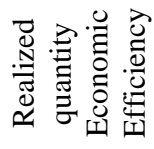 & 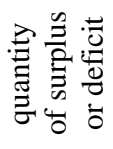 & 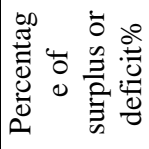 \\
\hline 50 & 87.5 & 69.8 & 17.7 & 20.2 & 113 & 7.5 & 14 & -6.5 & -86.7 \\
\hline 51 & 17.5 & 20.9 & -3.4 & -19.4 & 114 & 5 & 10.8 & $\begin{array}{l}-5.8 \\
\end{array}$ & -116.0 \\
\hline 52 & 6 & 13.1 & -7.1 & -118.3 & 115 & 30 & 36.2 & -6.2 & -20.7 \\
\hline 53 & 17.5 & 11 & 6.5 & 37.1 & 116 & 35 & 41.6 & -6.6 & -18.9 \\
\hline 54 & 40 & 21.9 & 18.1 & 45.3 & 117 & 5 & 10 & -5 & -100.0 \\
\hline 55 & 10 & 9.7 & 0.3 & 3.0 & 118 & 59.5 & 35 & 24.5 & 41.2 \\
\hline 56 & 35 & 36.8 & -1.8 & $\begin{array}{l}-5.1 \\
\end{array}$ & 119 & 7.5 & 11.9 & -4.4 & -58.7 \\
\hline 57 & 10.5 & 15 & -4.5 & -42.9 & 120 & 7.5 & 12.6 & -5.1 & -68.0 \\
\hline 58 & 35 & 39.2 & -4.2 & -12.0 & 121 & 20 & 23.6 & -3.6 & -18.0 \\
\hline 59 & 28 & 32.5 & -4.5 & -16.1 & 122 & 10 & 12.8 & -2.8 & -28.0 \\
\hline 60 & 40 & 22.9 & 17.1 & 42.8 & 123 & 12 & 9 & 3 & 25.0 \\
\hline 61 & 8 & 17.1 & -9.1 & -113.8 & 124 & 10 & 14 & -4 & -40.0 \\
\hline 62 & 18 & 13.9 & 4.1 & 22.8 & & & & & \\
\hline 63 & 12 & 15 & -3 & -25.0 & Average & 26.3 & 27.4 & -1.1 & -4.18 \\
\hline
\end{tabular}

Source: Prepared by the two researchers based on the data of the questionnaire and the DEAP statistical program

\section{Fifth resource: the amount of human labor}

The total amount of human work used for the total of the study sample was (141477) men / day with an average of (1141) men / day for each farm, and from the table (11) we note that the amount of human work achieved for economic efficiency reached on average (537) men / day that is, There is a surplus in the amount of human labor used (604) men / day, at a rate of (52.9\%). From the results of the analysis, it was found that (3) farms achieved complete economic efficiency and the deficit or surplus in the amount of human labor was equal to zero, and all the remaining farms (121) achieved a surplus, and no farm achieved a deficit.

Table (11): The amount of surplus or deficit in the amount of human labor for the study sample.

\begin{tabular}{|c|c|c|c|c|c|c|c|c|c|}
\hline \multicolumn{5}{|c|}{ Human work: Man / Day } & \multicolumn{5}{|c|}{ Human work: Man / Day } \\
\hline 寻 & 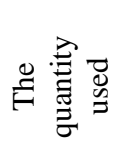 & 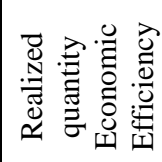 & 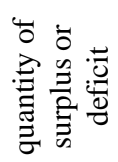 & 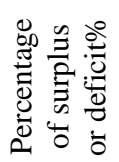 & 志 & 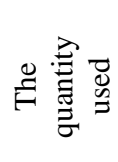 & 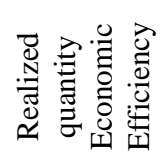 & 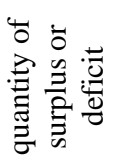 & 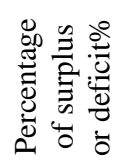 \\
\hline 1 & 1826 & 572 & 1254 & 68.7 & 64 & 605 & 282 & 323 & 53.4 \\
\hline 2 & 913 & 365 & 548 & 60.0 & 65 & 1154 & 406 & 748 & 64.8 \\
\hline 3 & 1061 & 442 & 619 & 58.3 & 66 & 713 & 306 & 407 & 57.1 \\
\hline 4 & 1504 & 448 & 1056 & 70.2 & 67 & 1840 & 627 & 1213 & 65.9 \\
\hline 5 & 521 & 241 & 280 & 53.7 & 68 & 574 & 296 & 278 & 48.4 \\
\hline
\end{tabular}


Mesopotamia J. of Agric.

Vo1. (48) No (3) 2020
ISSN: 2224 - 9796 (Online) جلـة زر اعـة الر افديـن

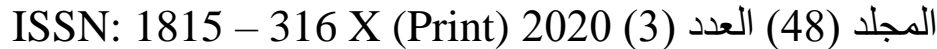

\begin{tabular}{|c|c|c|c|c|c|c|c|c|c|}
\hline \multicolumn{5}{|c|}{ Human work: Man / Day } & \multicolumn{5}{|c|}{ Human work: Man / Day } \\
\hline$\underset{\text { Iี工 }}{E}$ & 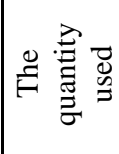 & 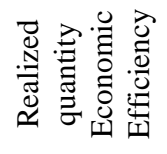 & 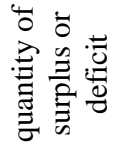 & 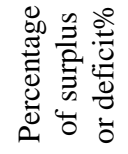 & $\underset{\Xi}{\Xi}$ & 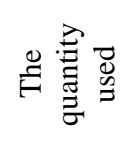 & 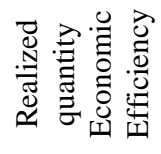 & 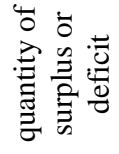 & 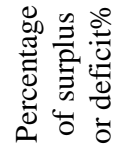 \\
\hline 6 & 877 & 313 & 564 & 64.3 & 69 & 1809 & 544 & 1265 & 69.9 \\
\hline 7 & 860 & 391 & 469 & 54.5 & 70 & 2396 & 805 & 1591 & 66.4 \\
\hline 8 & 3296 & 1134 & 2162 & 65.6 & 71 & 242 & 206 & 36 & 14.9 \\
\hline 9 & 655 & 365 & 290 & 44.3 & 72 & 986 & 416 & 570 & 57.8 \\
\hline 10 & 437 & 296 & 141 & 32.3 & 73 & 1173 & 451 & 722 & 61.6 \\
\hline 11 & 206 & 206 & 0.0 & 0.0 & 74 & 621 & 254 & 367 & 59.1 \\
\hline 12 & 826 & 351 & 475 & 57.5 & 75 & 2521 & 1369 & 1152 & 45.7 \\
\hline 13 & 2322 & 820 & 1502 & 64.7 & 76 & 2521 & 1369 & 1152 & 45.7 \\
\hline 14 & 1548 & 599 & 949 & 61.3 & 77 & 532 & 318 & 214 & 40.2 \\
\hline 15 & 2776 & 1129 & 1647 & 59.3 & 78 & 1009 & 444 & 565 & 56.0 \\
\hline 16 & 377 & 235 & 142 & 37.7 & 79 & 1247 & 468 & 779 & 62.5 \\
\hline 17 & 854 & 422 & 432 & 50.6 & 80 & 1928 & 830 & 1098 & 57.0 \\
\hline 18 & 768 & 339 & 429 & 55.9 & 81 & 787 & 339 & 448 & 56.9 \\
\hline 19 & 1306 & 659 & 647 & 49.5 & 82 & 893 & 396 & 497 & 55.7 \\
\hline 20 & 752 & 289 & 463 & 61.6 & 83 & 399 & 246 & 153 & 38.3 \\
\hline 21 & 664 & 306 & 358 & 53.9 & 84 & 512 & 287 & 225 & 43.9 \\
\hline 22 & 2425 & 934 & 1491 & 61.5 & 85 & 1940 & 761 & 1179 & 60.8 \\
\hline 23 & 2425 & 934 & 1491 & 61.5 & 86 & 970 & 460 & 510 & 52.6 \\
\hline 24 & 1007 & 416 & 591 & 58.7 & 87 & 688 & 448 & 240 & 34.9 \\
\hline 25 & 1780 & 820 & 960 & 53.9 & 88 & 2635 & 960 & 1675 & 63.6 \\
\hline 26 & 1374 & 496 & 878 & 63.9 & 89 & 999 & 525 & 474 & 47.4 \\
\hline 27 & 344 & 242 & 102 & 29.7 & 90 & 2656 & 1296 & 1360 & 51.2 \\
\hline 28 & 720 & 297 & 423 & 58.8 & 91 & 1243 & 499 & 744 & 59.9 \\
\hline 29 & 899 & 399 & 500 & 55.6 & 92 & 838 & 358 & 480 & 57.3 \\
\hline 30 & 977 & 977 & 0.0 & 0.0 & 93 & 1002 & 506 & 496 & 49.5 \\
\hline 31 & 331 & 282 & 49 & 14.8 & 94 & 430 & 306 & 124 & 28.8 \\
\hline 32 & 553 & 365 & 188 & 34.0 & 95 & 897 & 468 & 429 & 47.8 \\
\hline 33 & 2840 & 1051 & 1789 & 63.0 & 96 & 1916 & 893 & 1023 & 53.4 \\
\hline 34 & 489 & 251 & 238 & 48.7 & 97 & 4479 & 3208 & 1271 & 28.4 \\
\hline 35 & 713 & 360 & 353 & 49.5 & 98 & 3894 & 3894 & 0.0 & 0.0 \\
\hline 36 & 1394 & 473 & 921 & 66.1 & 99 & 475 & 265 & 210 & 44.2 \\
\hline 37 & 814 & 337 & 477 & 58.6 & 100 & 1578 & 606 & 972 & 61.6 \\
\hline 38 & 843 & 296 & 547 & 64.9 & 101 & 3522 & 2766 & 756 & 21.5 \\
\hline 39 & 1154 & 430 & 724 & 62.7 & 102 & 1119 & 489 & 630 & 56.3 \\
\hline 40 & 595 & 326 & 269 & 45.2 & 103 & 1320 & 530 & 790 & 59.8 \\
\hline 41 & 595 & 326 & 269 & 45.2 & 104 & 848 & 382 & 466 & 55.0 \\
\hline 42 & 968 & 368 & 600 & 62.0 & 105 & 466 & 296 & 170 & 36.5 \\
\hline 43 & 775 & 349 & 426 & 55.0 & 106 & 274 & 208 & 66 & 24.1 \\
\hline 44 & 786 & 266 & 520 & 66.2 & 107 & 634 & 420 & 214 & 33.8 \\
\hline 45 & 859 & 322 & 537 & 62.5 & 108 & 1215 & 554 & 661 & 54.4 \\
\hline 46 & 700 & 282 & 418 & 59.7 & 109 & 1215 & 554 & 661 & 54.4 \\
\hline 47 & 539 & 246 & 293 & 54.4 & 110 & 460 & 235 & 225 & 48.9 \\
\hline 48 & 518 & 285 & 233 & 45.0 & 111 & 1201 & 468 & 733 & 61.0 \\
\hline 49 & 304 & 216 & 88 & 28.9 & 112 & 1201 & 468 & 733 & 61.0 \\
\hline 50 & 3608 & 1752 & 1856 & 51.4 & 113 & 524 & 278 & 246 & 46.9 \\
\hline 51 & 722 & 377 & 345 & 47.8 & 114 & 376 & 230 & 146 & 38.8 \\
\hline 52 & 658 & 265 & 393 & 59.7 & 115 & 1858 & 598 & 1260 & 67.8 \\
\hline 53 & 559 & 235 & 324 & 58.0 & 116 & 1942 & 675 & 1267 & 65.2 \\
\hline 54 & 1310 & 392 & 918 & 70.1 & 117 & 313 & 220 & 93 & 29.7 \\
\hline 55 & 327 & 216 & 111 & 33.9 & 118 & 1804 & 580 & 1224 & 67.8 \\
\hline 56 & 1558 & 606 & 952 & 61.1 & 119 & 526 & 247 & 279 & 53.0 \\
\hline 57 & 468 & 292 & 176 & 37.6 & 120 & 406 & 258 & 148 & 36.5 \\
\hline 58 & 1668 & 641 & 1027 & 61.6 & 121 & 878 & 416 & 462 & 52.6 \\
\hline 59 & 1334 & 544 & 790 & 59.2 & 122 & 470 & 261 & 209 & 44.5 \\
\hline 60 & 1100 & 406 & 694 & 63.1 & 123 & 300 & 206 & 94 & 31.3 \\
\hline
\end{tabular}




\begin{tabular}{|c|c|c|c|c|c|c|c|c|c|}
\hline \multicolumn{5}{|c|}{ Human work: Man / Day } & \multicolumn{5}{|c|}{ Human work: Man / Day } \\
\hline 垔 & 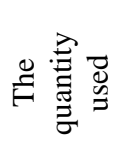 & 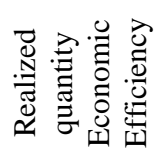 & 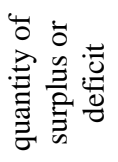 & 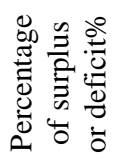 & 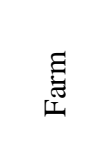 & 兽总 & 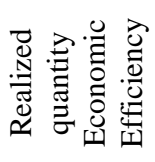 & 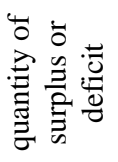 & 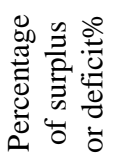 \\
\hline 61 & 535 & 323 & 212 & 39.6 & 124 & 560 & 278 & 282 & 50.4 \\
\hline 62 & 487 & 277 & 210 & 43.1 & & & & & \\
\hline 63 & 539 & 292 & 247 & 45.8 & Average & 1141 & 537 & 604 & 52.9 \\
\hline
\end{tabular}

Source: Prepared by the two researchers based on the data of the questionnaire and the DEAP statistical program

\section{CONCLUSIONS AND RECOMMENDATIONS}

The results of the economic efficiency assessment using a data envelope analysis method showed that the average Economic Efficiency was about (50.8\%), meaning that these farms can achieve the same level of production in light of the redistribution of economic resources, and provide a percentage of the quantities of resources used and reduce production costs by (49.2\%), and three farmers its rate $(2.4 \%)$ is complete technical, allocation and economic efficiency (100\%), meaning that it occurred at the points of contact between the equal output curve and the equal costs line as a result of its being able to achieve the maximum possible production with the lowest possible quantities of production inputs, and the lowest possible costs of production inputs, and when estimating the size of the economic resources achieved for economic efficiency through a method of analyzing the data envelope DEAP shows that most of the farms achieved a surplus in the use of most of the production elements by comparing the amount of resources actually used with their achieved efficiency Economic.

The study recommended the need for farmers to implement agricultural operations at the appropriate times for them, and to use the production elements in optimal quantities and according to the crop's need for them, as well as decisionmakers can study the reasons for the success of many of the farms that have achieved complete economic efficiency (100\%) to be references to farms that have not achieved economic efficiency, although they work in the same conditions to be followed in how to choose the optimal resource combination that lowers costs and maximizes profit.

\footnotetext{
دراسة الكفاءة الاقتصادية لمحصول الطماطة للموسم الانتاجي 2019 في محافظة نينوى ناحية زمار انموذجاً تطبيقياً

الخلاصة

هدفت الدراسة الى قياس الكفاءة الاقتصادية ومكوناتها الكفاءة التقنية والكفاءة التخصيصية من جانب المدخلات وعلى فرض تغير عوائد الحجم (VRS) وباستخدام اسلوب تحليل مغلف البيانات (DEA), وكذلك الاطلاع على هيكل وبنود تكاليف إنتاج محصول الطماطة, ومعرفة مدى تحقيق الوحدات الاقتصادية للاستخدام الرشيد لموارد الانتاج. جمعت البيانات اللازمة للدراسة ميدانياً من خلال استمارة استبانة نفذت بالمقابلة الثخصية لـ (124) من مزارعي محصول مدرل
} 
الطماطة بطريقة الزراعة المكشوفة في محافظة نينوى (ناحية زمار انموذجاً تطبيقياً) للموسم الانتاجي 2019, وشملت المتغيرات التفسيرية (البذور , الاسمدة, المبيدات, العمل الميكانيكي, العمل البشري) اما المتغير المعتمد فهو انتاج

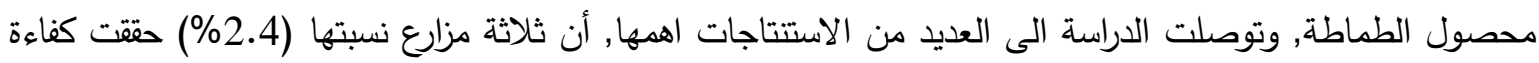
تقنية وتخصيصية واقتصادية كاملة (100\%) , واظهرت نتائج تقدير الكفاءة الاقتصادية أن متوسط الكفاءة الاقتصادية بلغ نحو (50.8\%), اي أن هذه المزارع بإمكانها تحقيق المستوى نفسه من الانتاج في ظل تخفيض تكاليف الانتاج بنسبة (49.2\%), واوصت الدراسة بضرورة استخدام المزارعين للموارد الاقتصادية وفق احتياج المحصول لهذه الموارد وبالثكل الذي يدني التكاليف ويعظم الربح, ومن الضروري أن تدرس اسباب نجاح العديد من المزارع التي حققت كفاءة اقتصادية كاملة (100\%) لتكون مراجع للمزارع التي لم تحقق الكفاءة الاقتصادية على الرغم من انها تعمل في نفس الفرئ الظروف.

الكلمات المفتاحية: الكفاءة الاقتصادية, الكفاءة التقنية, الكفاءة التخصيصية, محصول الطماطة. تاريخ استلام البحث: 2020/7/23، وقبوله:2020/8/12

\section{REFERENCES}

Ali, I. H. (2014). Measuring Economic Efficiency and Determining the Economic Size of Diyala Governorate Farms. Doctor's thesis / Agricultural Economics Department, College of Agriculture, University of Baghdad. Al-Rashidi, M.(2018). Quantitative Methods in Administration, College of Business Administration, King Faisal University, Deanship of E-Learning and Distance Education.

Banker, R. D.( 1984). Estimating Most Productive Scale Size Using Data Envelopment Analysis . European Journal of Operational Research 217.

Charnes, A. Cooper, W. W. and Rhodes, E. , (1978). Measurement the Efficiency of Decision Making units. European Journal of Operational Research, 2.

Cooper, S .T. (2003). Data Envelopment Analysis: Acomprehensive Text with Models ,Applications ,Refernces and DEA-Solver Software , Kluwer Academic Publishers Group, Norwell ,Massachusetts 02061 USA.

Debertin, L. D. (2012). Agricultural Production Economic Second Edition Macmillan Publishing Company, USA .

El-Saqa, M. I. (2008). Analysis of the Technical Competence of Banks in the State of Kuwait Using the Data Encryption Analysis, Scientific Journal of Economics and Administration, Faculty of Commerce, Ain Shams University, No. 2.

Farrell , M.J.(1957). The Measurement of Productive Efficiency. Journal of the Royal Statistical Society, A, 120, No , 3, P: 253-290.

Rubenstein, R ,(2005). The Reliability of School Efficienc Measures Using Data Envelopment Analysis, In:L.Stiefel. A. Schwartz; R. Rubenstein. And J. zabel 